\title{
Occurrence and correlation between the numbers of Black-headed Gull Chroicocephalus ridibundus and Yellow-legged Gull Larus michahellis on Kolut fish ponds (Serbia)
}

\author{
Marko Tucakov ${ }^{1 *}$, Milan Vogrin ${ }^{2}$
}

\begin{abstract}
Presence and correlation between the numbers of Blackheaded and Yellow-legged Gull was studies between 1998 and 2004 on Kolut fishponds in NW Serbia. Both species occurred there from February to December. Spring migration culminated in late February and early March. The period of the most intensive autumn concentration was from October to December. The difference between the numbers in all months as well as between the numbers in spring and in autumn was statistically significant. The period of the most intensive autumn passage of Yellow-legged Gull was from late October to early December. The difference between the numbers between the months was not statistically significant. A high concentration of both species in autumn and early winter was explained by high food availability during fish harvest when ponds were empty. Positive correlation between the numbers of two species thru the year indicated attractiveness of large flocks of Black-headed Gulls for Yellow-legged Gulls. This is especially true for the autumn period, when feeding niches and food is easily accessible. Correlation between the numbers of two species was negative in spring, when accesibility of aquatic animals is lower and large flocks of Black-headed Gulls are lacking.
\end{abstract}

Key words: Black-headed Gull, Chroicocephalus ridibundus, Yellow-legged Gull, Larus michahellis, Serbia, migration, wintering.

Riassunto - Consistenza e correlazioni fra il Gabbiano comune e il Gabbiano reale mediterraneo nelle peschiere di Kolut (Serbia).

La presenza e correlazione tra le consistenze delle popolazioni di Gabbiano comune e di Gabbiano reale mediterraneo sono state studiate negli stagni di Kolut (Serbia Nord-occidentale) tra il 1998 e il 2004. Entrambe le specie erano presenti da febbraio a dicembre. La migrazione primaverile culminava a fine febbraio e inizio marzo. Il periodo di più intensa concentrazione autunnale andava da ottobre a dicembre. Le differenze tra le consistenze, in tutti i mesi, così come in primavera e in autunno erano statisticamente significative. Per il gabbiano reale mediterraneo, il periodo del passaggio autunnale più intenso andava da fine ottobre ai primi di dicembre; la differenza tra i mesi non era statisticamente significativa. Un'elevata concentrazione di entrambe le specie in autunno e all'inizio dell'inverno viene spiegata dalla grande disponibilità di cibo durante la raccolta del pesce, quando gli stagni ven-

\footnotetext{
${ }^{1}$ Danila Kiša 41/35, 21000 Novi Sad, Serbia

E-mail: markotucakov1@gmail.com

${ }^{2} \mathrm{Zg}$. Hajdina 83c, SI-2288 Hajdina, Slovenia

E-mail: milan.vogrin@guest.arnes.si

* Corresponding author: markotucakov1@gmail.com

(C) Marko Tucakov, Milan Vogrin
}

Received: $23^{\text {th }}$ October 2014

Accepted for publication: $17^{\text {th }}$ February 2015 gono progressivamente svuotati. La correlazione positiva tra il numero di individui delle due specie nel corso dell'anno sembra indicare un effetto attrattivo dei grandi stormi di gabbiani comuni sui gabbiani reali. Questo è particolarmente vero per il periodo autunnale, quando il cibo è facilmente accessibile. La correlazione tra le due specie era negativo in primavera, quando l'accessibilità delle prede acquatiche era inferiore ed erano assenti i grandi stormi di gabbiano comune.

Parole chiave: gabbiano comune, Chroicocephalus ridibundus, gabbiano reale, Larus michahellis, Serbia, migrazione, svernamento.

\section{INTRODUCTION}

Black-headed Gull breeds in Serbia, primarily on wetlands of different origin in northern province of Vojvodina, and its breeding distribution is satisfactorily documented. It is present in all seasons. Its numbers in 2008 was 3,137-3,438 breeding pairs in the country (Tucakov et al., 2009). Yellow-legged Gull did not bred in Serbia, although its occurrence was confirmed throughout the year in variety of habitats (Tucakov et al., 2009; own data). The closest breeding colonies are on the eastern coast of the Adriatic Sea, in southern Dalmatia (Rubinić, 2003) and in north-eastern Bulgaria (Dereliev et al., 2010), not including recent breeding records from Hungary (BirdLife International, 2004).

Both species are present on fishponds, as well, but there are no studies of their occurrence, seasonal changes in their numbers and reasons for these changes. Therefore, the aim of this article is to present and discuss migration pattern of both species and correlations between their numbers on Kolut fish farm, man-made wetland in Vojvodina, NW Serbia. Since none of these gulls breed on the study site nor in its vicinity, the results are expected to give clear picture about the migration pattern.

\section{MATERIALS AND METHODS}

\footnotetext{
Study area

Kolut fish farm is situated on the edge of village Kolut (UTM CR $48,45^{\circ} 53^{\prime} \mathrm{N} 18^{\circ} 57^{\prime} \mathrm{E}$ ). Danubian type of continental clime is characteristic for the area, with the highest average temperature in July $\left(20,9^{\circ} \mathrm{C}\right)$ and the lowest in January $\left(-0,9^{\circ} \mathrm{C}\right)$. The highest precipitation is recorded in June, the lowest is in February, while yearly average is $569 \mathrm{~mm}$ (Tomić, 1996).
} 
The dominant fish species is Carp Cyprinus carpio, but rearing of small percent of Grass Carp Ctenopharyngodon idella, Silver Carp Hypophtalamychtis molitrix, Bighead Carp Hypophalamychtis nobilis, Wels Catfish Silurus glanis, Zander Stizostedion lucioperca and Pike Esox lucius takes place, as well. At the moment of study, 175 ha was in usage. Fish production took place in eight large ponds, while 10 small ones serve for wintering storage (Barkjaktarov, 2004). All ponds receive water from the river Plazović. Fish feeding started in April. Fattening technology included ocasional enhancing of benthos production by fertilizers, as well as water calcification throughout the year. Fish fattening lasted until the late September, after when emptying of ponds took place, and lasted up to one month. Fish harvesting ended by the mid December, but the ponds stayed empty until the end of February. However, the ratio of empty ponds and surface covered with water throughout the winter was approximately 50\%-: since fish production lasted at least two years, just twoyear individuals being harvested, while other hibernated.

Shallow banks of all ponds and several small islets within the ponds were covered by dense emerging vegetation (Phragmites australis, Typha sp.). During vegetation season submerging vegetation (Myriophyllum sp., Ceratophylum sp.) covered majority of pond bottoms, while flotant (Nymphaea alba) was developed just patchily. Within the fish farm area there are groups of Blackthorn Prunus nigra, White Willow Salix alba, White Poplar Populus alba, Goat Willow S. caprea, and Grey Willow $S$. cinerea, growing on the pond edges. The fish farm is surrounded with agricultural fields, marshy depressions of the Plazović and the gardens of village Kolut.

\section{METHODS}

118 visits to the Kolut fishponds were made between July $4^{\text {th }}, 1998$ and May $15^{\text {th }}, 2004$, between 6 and 12 AM when the entire surface of all ponds was examined from the embankments situated between the ponds, using points from which all parts of this site were clearly visible. Total number of observation hours was 351. All individuals of two species registered in the study area were counted. It was assumed that few birds were overlooked.

For the purpose of comprehensive analysis of this species' presence, monthly data was divided into three decades Average number of birds present on the fish farm in each ten-day period was calculated and taken into account in drawing the graph.

Relationship between numbers of two species was presented taking into account just the visits to the study area when both species occurred.
Statistical analyses were performed with non-parametric Kruskal-Wallis and Mann-Whitney tests and with Spearman correlation coefficient (Sokal \& Rohlf, 1995). Data were analyzed using the SPSS 8.0 statistical program.

Since we start with the study well before the split between Larus michahellis and L. cachinnans was accepted (Beaman \& Madge, 1998) we use the name Yellowlegged Gull for both species in this article. However we should take into account that most of large gulls in our study area was Larus michahellis.

\section{RESULTS}

Presence of the Black-headed Gull was detected throughout the year excluding January (Fig. 1). Presence of Yellow-legged Gull was recorded from late December to late September was very scarce (Fig. 2). Maximal and mean numbers for both species are presented in Tab. 1 .

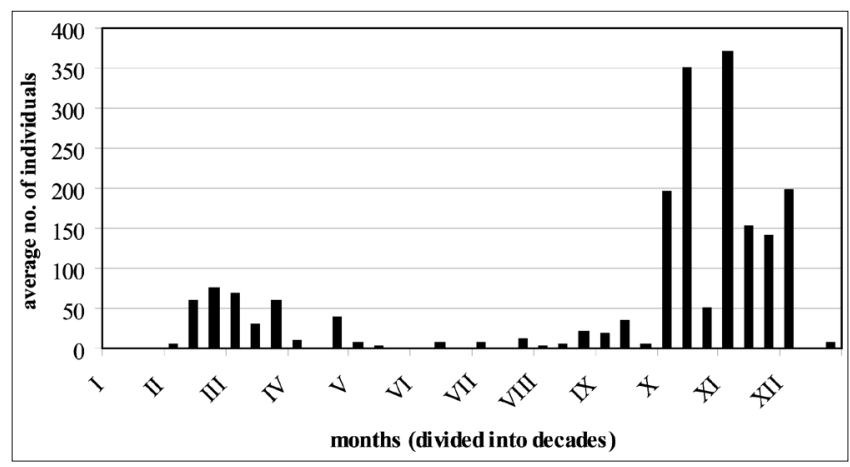

Fig. 1 - Average number of Black-headed Gulls Chroicocephalus ridibundus per ten-day periods over the year at the Kolut fishponds between 1998 and 2004.

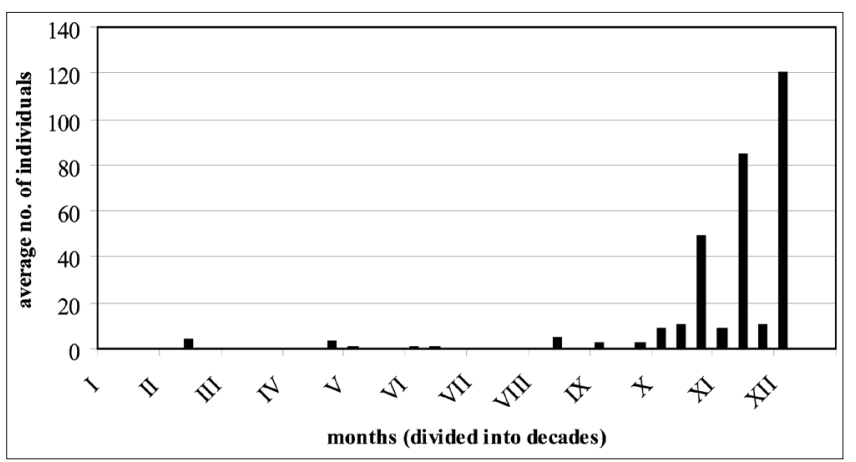

Fig. 2 - Average number of Yellow-legged Gulls Larus michahellis per ten-day periods over the year at the Kolut fishponds between 1998 and 2004.

Tab. 1 - Number of the Black-headed Gull Chroicocephalus ridibundus and Yellow-legged Gull Larus michahellis occurring on Kolut ponds in the study period.

\begin{tabular}{|l|c|c|c|}
\hline Species & Maximal number & Mean number & Standard deviation \\
\hline Chroicocephalus ridibundus & 800 & 57.9 & 128.6 \\
\hline Larus michahellis & 340 & 8.3 & 38.9 \\
\hline
\end{tabular}




\section{Black-headed Gull}

Black-headed Gull occurence was recorded in 51.82\% of field visits to the studied site. First spring data originate from early February (February $5^{\text {th }} 2001,15$ individuals). Spring migration was poorly pronounced and culminated in late February and early March. Although birds were present also within the breeding period, numbers was low, never exceedintg 12 individuals in average. The period of the most intensive autumn migration was from early October to early December. Last individuals were reecorded in late December.

Difference between the numbers of Black-headed Gulls between all months were statistically significant (Kruskal-Wallis test, $\mathrm{Chi}^{2}=45.15, \mathrm{df}=11, \mathrm{P}<0.001$ ), which was true also for the difference between the numbers occurring in spring (from February to April) and autumn (from September to November) migration: Mann-Whitney U test, $\mathrm{U}=375.0, \mathrm{P}<0.05$.

\section{Yellow-legged Gull}

Frequency of Yellow-legged Gull occurence was recorded in $37,96 \%$ of field visits. First individuals in spring appeare in early February, while maximal number prior to autumn has never exceeded 5 individuals (on April 24 2002). The period of the most intensive autumn passage was from late October to early December. Last individuals were recorded in late December. The difference between the numbers of Yellow-legged Gulls between the months was not statistically significant (Kruskal-Wallis test, $\mathrm{Chi}^{2}=7.42, \mathrm{df}=11, \mathrm{P}>0.05$ ).

In order to test the correlation between the numbers of two gull species, we compared also the numbers of individuals of both species occurring in the same time in the study area. It was statistically significant (Spearman, $\mathrm{rs}=0.27, \mathrm{P}<0.005, \mathrm{~N}=118$ ): the numbers of Yellow-legged Gulls grew when numbers of Black-headed Gulls did so. The correlation was significant for the autumn months, as well ( $\mathrm{rs}=0.38, \mathrm{P}<0.05, \mathrm{~N}=30$ ), but not for the spring months ( $\mathrm{rs}=0.48, \mathrm{P}>0.05, \mathrm{~N}=38$ ).

\section{DISCUSSION}

Both gull species regularly occur throughout the year on all studied fishponds in Serbia (Puzović, 1999), on rivers (Gergelj et al., 2000; Stojnić, 2000; own data) and on natural lakes (Lukač \& Ternovac, 1990; Ternovac \& Lukač, 1989).

\section{Black-headed Gull}

The largest numbers of Black-headed Gull on Ečka fish farm in spring occurred in early March (Pekić, 1958), while on Bečej fish farm spring peak was recorded in April (Lukač $\&$ Lukač, 1992). These data are in correspondence to our findings (Fig. 1), as well as the data on the largest numbers in Czech Republic (Vavrik, 1998) and Northeast Slovenia (Gregori, 1989; own data), and other places in Central Europe (see Olsen \& Larsson, 2003). Numbers during period of breeding remain low on non-breeding fishponds (Lukač et al., 1995), while post-breeding dispersal results in very high concentrations on some places in August (Gergelj et al., 2000; Ternovac \& Lukač, 1989). Presumably, these places were used for roosting, in contrary to our study site, where roosting was not observed. Period of autumn migration attracts the largest flocks during the year on fishponds (Pekić, 1958; Mikuska et al., 2002; Agošton, 2004), which was also truth on Kolut fish farm (Fig. 1).

\section{Yellow-legged Gull}

Spring and autumn concentrations on our study site were similarly pronounced like in other wetlands in Vojvodina (Dimitrijević, 1977). It has been suggested that autumn increase in numbers on Ečka fishponds is due to the fish harvest which occur in that period (Dimitrijević, 1977), which was confirmed by our study. The Yellowlegged Gull was lacking in Kolut ponds when it was frozen (Fig. 2). The peak of its number on the roosting site on the Danube was reached in that period: late January and early February (Stojnić, 2000).

\section{Autumn concentrations}

High concentrations of both studied species in autumn and early winter are very characteristic feature of their occurrence on Kolut ponds (Figs. 1 and 2). This was in connection with easily available and abundant prey. At that time water flows out of the ponds and fish harvest takes place. Fish and other aquatic animals were concentrated in the depressions on the bottom of the ponds, prior to fish netting. That must be one of the reasons for the high number of Black-headed Gull and Yellow-legged Gull from early October untill the water or mud freeze (Figs. 1 and 2). An additional reason is that this period partly coincide with the autumn migration (Cramp, 1998). During period of fish harvest many ponds are shallow, empty, and their foraging value is very high. The highest numbers of Great White Egret Egretta alba and Grey Heron Ardea cinerea were also noticed in that period of year (Tucakov, 2004, 2005), confirming high importance of such feeding conditions for birds which consume small aquatic animals.

Positive correlation between the numbers of two species throughout the year, especially during autumn, probably indicates attractiveness of large foraging flocks of Blackheaded Gulls for Yellow-legged Gulls. This is especially true for the autumn period, when suitable feeding areas and food is easily accessible. In spring, when accesibility of aquatic animals is lower, large flocks of Black-headed Gulls lack, and correlation between the numbers of two species was not significant (see statistical analysis). However, it was proven that larger gull species such as Herring Gull $L$. argentatus are more dominant on the feeding sites, despite more numerous Black-headed Gulls (Bellebaum, 2005).

\section{Wintering}

Wintering of both studied species was not detected on Kolut fish farm, which also corresponds with other fish farms (Tadić, pers. com). The reason for this was lack of feeding possibilities caused by freezing of ponds. Rivers are, therefore, much more suitable for wintering of Blackheaded and Yellow-legged gulls in northern Serbia (e.g.: Dajović, 1997; Stojnić, 2000). Roosting sites on lakes are exception (Lukač \& Ternovac, 1990): they might stay unfrozen due to high abundance and activity of these and other waterbird species. 


\section{REFERENCES}

Agošton A., 2004 - Bird inventorisation at Novi Kneževac fishpond with population estimates for breeders. Ciconia, 13: 88-93 (in Serbian with English summary).

Barjaktarov D., 2004 - Ecology and ethology of Great Crested Grebe (Podiceps cristatus L.) in Vojvodina. Master thesis. Novi Sad: University of Novi Sad, Dfaculty of Sciences, Department of Biology and Ecology (in Serbian).

Beaman M. \& Madge S., 1998 - The Handbook of Bird Identification for Europe and the Western Palearctic. London:Christopher Helm. A\&C Black.

Bellebaum J., 2005 - Between the Herring Gull Larus argentatus and the bulldozer: Black-headed Gull Larus ridibundus feeding sites on a refuse dump. Ornis Fennica, 82: 166-171.

BirdLife International, 2004 - Birds in Europe: population estimates, trends and conservation status. Cambridge: BirdLife International. University Press.

Cramp S., 1998 - The Complete Birds of the Western Palaearctic on CR ROM. Oxford: Oxford.

Dajović M., 1997 - Results of bird monitoring in Belgrade area in 1990-1997 period. Ciconia, 7: 39-54.

Dereliev S., Madiarov M. \& Cheshmedzhiev S., 2010 Larus (cachinnans) michahellis Yellow-legged Gull. In: Iankov P. (ed.), Atlas of Breeding Birds in Bulgaria. Sofia: BSPB, (pp. 282-283).

Dimitrijević S., 1977 - Charadriiformes in the Province of Vojvodina. Larus, 29-30: 5-32.

Gergelj J., Tot L. \& Frank Z., 2000 - Birds of Tisa area from Kanjiza to Novi Becej. Ciconia, 9: 121-158 (in Serbian with English summary).

Gregori J., 1989 - Fauna and ecology of birds in Pesnica valley (NE Slovenia, Yugoslavia). Scopolia, 19: 1-59 (in Slovene with English summary).

Lukač Š. \& Lukač A., 1992 - Ornithofauna of the fishpond «Bečej». Ciconia, 4: 4-27 (in Serbian with English summary).

Lukač Š. \& Ternovac T., 1990 - Notes on ornithofauna of Slano Kopovo from 1987 to 1989. Ciconia, 2: 50-63 (in Serbian with English summary).

Lukač Ž., Gubik D. \& Kovač S., 1995 - Material for the ornithofauna of the fishpond Futog. Ciconia, 5: 59-66 (in Serbian with English summary).

Mikuska J., Mikuska T. \& Romulić M., 2002 - Vodič kroz biološku raznolikost Kopačkog rita: Ptice. Osijek: Matica hrvatska Osijek and Javna ustanova Park Prirode Kopački rit.

Olsen K.M. \& Larsson H., 2003 - Gulls of North America, Europe and Asia. Princeton and Oxford; Princeton University Press.

Pekić B., 1958 - A contribution to the knowledge of the birds of Carska Bara and its environment. Zaštita prirode, 14: 11-19 (in Serbian with English summary).

Puzović S., 1999 - Usklađivanje intenzivnog gajenja riba i očuvanja raznovrsne faune ptica na šaranskim ribnjacima u Vojvodini. In: Šimić S. \& Ivanc A. (eds.). Zaštita životne sredine pri intenzivnom gajenju riba. Novi Sad: Univerzitet u Novom Sadu, Prirodno matematički fakultet, Institut za biologiju \& Ekološki pokret grada Novog Sada (pp. 164-179).
Rubinić B., 2003 - Phenology and abundance of Gulls Laridae in Southern Dalmatia (Croatia). Acrocephalus, 24: 135-143.

Sokal R.R. \& Rohlf F.J., 1995 - Biometry. The principles and practice of statistics in biological research. New York: W.H. Freeman and Company.

Stojnić N., 2000 - Zimska posmatranja ptica vodenih staništa na Dunavu kod Ćerevića. Ciconia, 9: 111113.

Ternovac T. \& Lukač Š., 1989 - Notes on ornithofauna of Slano Kopovo in 1986. Ciconia, 1: 26-30 (in Serbian with English summary).

Tomić P., 1996 - Klima. In: Đuričić J. (ed.), Opština Sombor. Prirodno - matematički fakultet, Institut za geografiju \& Prosveta, Novi Sad - Sombor (pp. 16-21) (in Serbian).

Tucakov M., 2004 - Migration dynamic and wintering of Great White Egret Egretta alba on Kolut fishpond in northern Serbia. Biota, 5: 59-66.

Tucakov M., 2005 - Seasonal changes in the number of the Grey Heron Ardea cinerea occuring on Kolut fishponds in northern Serbia. Ornis Svecica, 15: 113-117.

Tucakov M., Ham I., Gergelj J., Barna K., Žuljević A., Sekereš O., Sekulić G., Vučanović M., Balog I., Radišić D., Vig L., Hulo I., Simić D., Skorić S., Stojnić N., Spremo N., Ružić M., Puzović S., Stanković B., Grujić D. \& Lukač Š., 2009 - Gull and tern colonies in Serbia. Ciconia, 18: 29-80 (in Serbian with English summary).

Vavrik M., 1998 - Six years of study of spring migration at Šmvaldsky pond - attempt at objectivization of faunistic. Zpravy MOS, 56: 55-89. 